\title{
Correction to: Minimally invasive video-assisted thyroidectomy (MIVAT): the quest for a scarless approach
}

\author{
Alberto Mangano ${ }^{1} \cdot$ Cesare Carlo Ferrari $^{1} \cdot$ Gianlorenzo Dionigi ${ }^{1}$
}

Published online: 2 February 2021

○) Springer Science+Business Media, LLC, part of Springer Nature 2021

\section{Correction to: Surgical Endoscopy (2014) 28:1386-1387 https://doi.org/10.1007/s00464-013-3293-9}

This article was updated to correct the author listing of Cesare Carlo Ferrari and Gianlorenzo Dionigi, whose given names and surnames were reversed.
Publisher's Note Springer Nature remains neutral with regard to jurisdictional claims in published maps and institutional affiliations.

The original article can be found online at https://doi.org/10.1007/ s00464-013-3293-9.

Alberto Mangano

alberto.mangano@gmail.com

1 1st Division of General Surgery, Endocrine Surgery Research Center, Department of Surgical Sciences and Human Morphology, University of Insubria, Varese, Italy 